\title{
Clinical trials from the perspective of the sociology of medicine
}

\author{
Beata Tobiasz-Adamczyk
}

\begin{abstract}
Zakład Socjologii Medycyny, Katedra Epidemiologii i Medycyny Zapobiegawczej, Collegium Medicum Uniwersytet Jagielloński

Address for correspondence: Beata Tobiasz-Adamczyk, Zakład Socjologii Medycyny, Katedra Epidemiologii i Medycyny Zapobiegawczej, ul. Kopernika 7a, 31-034 Kraków, phone+48 124223 182, mytobias@cyf-kr.edu.pl
\end{abstract}

\section{Abstract}

Although clinical trials are rarely of interest to medical sociologists, in the last decades there has been increased focus on the processes of medicalization as well on the social critical approach to these multidimensional phenomena by health sociologists. From the perspective of the sociology of illness, clinical trials could be perceived as a bridge between the 'society of remission' and 'risk society'. Public opinion polls did not give a clear answer regarding the social attitudes and the level of social trust presented by Poles towards clinical trials although patients or healthy volunteers are the main subject of this research. Creating an atmosphere of social trust (using the role of mass-media) towards clinical trials (through social awareness, methods of investigation and using the results in everyday medical practice) gives a chance to create a new 'quality of relations' between scientific teams responsible for clinical trials and society.

\section{Key words: sociology of illness, clinical trials, social awareness and attitudes towards clinical trials}

Stowa kluczowe: socjologia choroby, badania kliniczne, wiedza i postawy spoteczne

Ministerstwo Nauki i Szkolnictwa Wyższego
Przygotowanie do wydania elektronicznego finansowane w ramach umowy 641/P-DUN/2018 ze środków Ministra Nauki i Szkolnictwa Wyższego przeznaczonych na działalność upowszechniającą naukę.

\section{Introduction}

In the last decades medical sociologists, especially health sociologists, have shown unprecedented interest in the processes of medicalization in its various dimensions and at different levels of social impact [1-3], as evidenced by entire monographs devoted to this complex and multidimensional process [4]. It is an attempt to transfer onto Polish soil the theoretical assumptions and observations based on reflection and experiences on 'medical imperialism' in the form of interference of medicine in the daily functioning of modern societies. Admittedly, Polish medicine has adopted the trend and has fully taken on a dictatorial role with regard not only to lifestyle, but also to other behaviours. However, in the broadly considered issues regarding the processes of medicalization, pharmaceuticalization and biotechnology of social life [5], indicating that medicine took control over social life, the issue of clinical research has so far not been of special interest to medical sociologists, particularly in relation to the sociology of illness.

In the article Medicalization - the perspective of the usurper, A. Ostrowska affirms that "the doctor's voice should be decisive in many issues where death, suffering, quality of life, pain and dying are at stake", but adds: "the created faith in the possibilities and exclusiveness of medicine has made the doctor insufficiently respectful of patient subjectivity and the principle of partnership in mutual relations" [1, p. 43]. The author also points to the fact that "certain attributes of professional domination 
are also the result of social pressure and the actions of specific pressure groups composed of health care users (...). The primary goal of doctors' activities is treatment, and further, improvement of the patient's quality of life" [1, p. 47]. The implementation of these goals is directly and indirectly carried out by clinical research. Therefore, a question may be raised whether they are a manifestation of a positive or negative impact of medicalization.

The perspective of the sociology of illness allows finding links between the various stages of the social process of the illness, which has its beginning (assuming the role of an ill person), a social course connected with a certain trajectory, depending on the duration of the process and the ability to control its course and the final stage, which can mean "approaching recovery" or vice versa - the stage of dying, of variable duration $[6,7]$. According to Giddens [8], illness as a life experience [9], includes the process of subjective describing the selfperspective of illness behaviours, based on interpretation and actions undertaken by the patient. In this context also clinical trials could be situated.

Regardless of the degree of awareness of the impact of medicalization, the relationship between medicine and society has always focused on two basic values, i.e. human life and health; however, in recent decades, these interconnected relationships have undergone profound transformations and become much more complex, primarily as a result of civilization changes, increase in general awareness, technological progress and new scientific discoveries. Social determinants of changes in these relations result not only from the impact of civilization progress on living standards and general quality of life, changes in lifestyles, increase of behaviours that do not necessarily treat health as a 'desirable value', and persisting social inequalities, consequently leading to inequalities in health status. Deep changes in all dimensions of social life (also under the influence of medicalization), have significantly influenced the expected scenarios of developing "the entire living space", at the same time leading to the emergence of new threats of not only civilization, but also health, nature.

Demographic changes observed in developed countries, associated with extending the average life expectancy (thanks to controlling a majority of infectious diseases), have had a significant impact on the epidemiological changes in the course of diseases (chiefly observed since the second half of the twentieth century), and led to new challenges faced not only in medicine, but equally in social reactions to the process of the medicalization of social life. They have become an impulse for adopting a new perspective on the fight against chronic diseases, which constitute social problems, both in the global dimension and in relation to particular societies. The rapid aging of societies, the severity of chronic diseases and the accompanying disability, have caused a clash of medicine with a new 'quality of illnesses' regarding morbidity and in the reported causes of mortality. These sometimes dramatic transformations have become the basis for new challenges facing medicine, but also for new expectations of society regarding the broadly understood medicine, medical professionals, scientists working in the area of basic science, as well as researchers carrying out clinical trials bridging the gap between scientific experience and introducing the results of these experiences into everyday medical practice in the form of new treatment or pharmacotherapy.

These expectations resulted from appreciating the fact and awareness that there is no possibility of further systematic development of medicine without scientific research - the position of medicine and society on this issue is usually compatible, based on the belief that the chances of recovery depend on the treatment methods used and in the case of many illnesses, waiting for new methods of treatment is tantamount to extending life. Advances in medicine are an integral part of the progress of civilization, including challenges faced by medicine in the pursuit of the aetiology of diseases, especially chronic ones, changing the definition of 'incurable' to 'curable', expanding knowledge about their effective treatment or curing the disease.

Although these expectations are shared by both sides, i.e. the world of medicine and society, they have a different perspective on the process of achieving medical success and new methods.

What seems obvious to the representatives of medical professions and research teams working on new methods of treatment is not similarly perceived, evaluated or appreciated by various social groups of recipients, i.e. patients treated for various reasons.

The basic question - on the one hand - are the methods of conducting further scientific research on effective treatment methods, lowering the mortality rate due to civilization diseases, and on the other - the impact of the process of medicalization (its positive and negative dimensions) on the role and importance attributed to clinical research in public awareness, in a society that is not immune to life-threatening diseases, taking their toll in all age groups. Often, the very term 'clinical trial' is incomprehensible or falsely understood, and accompanied by various types of emotions, not always positive.

Also, the messages communicated to the general public, i.e. criticism of the process of medicalization, indicating examples of 'selling sickness', is not conducive to building a positive attitude towards clinical trials [10]. The overwhelming influence of the medicalization process on everyday social life has led to the emergence of a society dependent on drugs, a drug-dependent society, consequently dependent on the products proposed by pharmaceutical concerns and the unclear role of clinical trials sponsors controlling their results, which raises the question of how the published results are objective, fair and independent of sponsors [11].

There is a dearth of information that is communicated to society about various aspects of clinical trials, in particular about the rules of recruitment for research (the more so that often the rules of inclusion or exclusion are not understood by lay people, which raises concerns and suspicions about the integrity or privileged position of the people included in research) and the anticipated effects of research in a given field of medicine that are 
beneficial to people suffering from a specific disease. This leads us to the next question - why many clinical trials are conducted in certain groups of diseases (e.g. cancer, cardiovascular system), and less so in other, and therefore, what the premises for undertaking research are and how the public should be (in a way that would be understandable for them) informed about the scope of clinical trials and related costs, both economic and social. Public opinion polls on clinical trials show a lack of trust in the information provided on clinical trials, indirectly confirming distrust of the very idea of these studies, resulting from the fact that knowledge about them is transmitted inadequately [12].

The struggle that the purpose of clinical trials be understood is connected with the necessity of overcoming stereotypes and biases against these studies, without which medical progress is impossible and without which there would be no new therapies. All the same, it is difficult to refute the view existing in social consciousness, namely of patients being used as 'guinea pigs'. Rebutting this myth should reinforce the belief that without the participation of the sick (patients, volunteers) there is no possibility to try out new therapeutic methods.

The socio-cultural context should also be taken into account, which clashed against the successive stages of the medicalization process, both in the dimension of positive medicalization and manifestations of negative medicalization, criticized from the perspective of various social actors.

The impatience caused by failed applications of certain therapies is associated with expectations of new, more effective drugs. Patients often do not take into account the fact that those drugs that have not passed clinical trials cannot be included in standard therapies or allowed to be sold on the pharmaceutical market.

\section{Social expectations reyarding clinical trials}

Clinical trials do not attract special attention in the public's general awareness - even the media's publicized achievements in the form of spectacular discoveries of new therapeutic methods, actually changing the state of knowledge and medical expertise, are often barely noticed as the 'news of the day'. There is a widespread view that clinical trials are not of interest to healthy people who want to 'push away' the idea of disease and suffering.

Low interest in clinical research taken by healthy people is often accompanied by lack of reliable knowledge about the purpose of such research, leading to the dissemination of many false and negative stereotypes and myths, and the emergence of a variety of social attitudes towards clinical trials.

The degree of interest in clinical trials is radically increased in the face of threats to one's own health or the health of our dearest, especially children. In such circumstances, especially in the case of a disease that is very difficult to cure or which is considered incurable, the interest in new treatment methods grows rapidly, and so does hope and anticipation of a new, more effective drug, which would give a chance to heal the disease or improve the quality of life in a situation of a permanent threat to health or life. This faith and hope are associated with the expectation to change the position of the patient, from "being a victim of a given disease, often identified with the death sentence" to the position of "a person who overcame a disease, who has succeeded, who has been successfully cured", although many times success means only delaying the risk of losing one's life. In the case of an incurable disease associated with pain and suffering, expectation means the possibility of obtaining a more effective drug that would relieve severe pain and suffering.

In post-modern society, analyzing the contemporary multidimensional association between the social determinants of health status involving a relationship between society and the causes of disease or the health risks, clinical trials can be placed on the axis building a bridge between the so-called 'remission society' and 'risk society' [13]. According to Frank [14], remission society consists of an increasing number of people who have undergone a specific disease and are now considered cured, which does not mean that their health may not deteriorate and the disease return, e.g. in the form of cancer. As the term itself indicates - 'remission' does not entail a guarantee of being completely healed, elimination of the recurrence of the disease, but for this category of people clinical trials are a chance to counteract or control the recurrence of the disease, not allowing relapse. Regarding the other end of this axis, we can refer to Beck's risk society [15], in which, along with other known and unknown threats, clinical trials may be associated with the risk of introducing new, not completely tested methods of treatment (e.g. in the form a new drug) or be a source of other threats, such as using all possible therapeutic methods.

Epidemiological indicators, for example in the form of data on mortality due to specific diseases or morbidity for various reasons, clearly show groups of patients requiring medical intervention. Therefore, it is worthwhile asking whether criticizing the process of medicalization by seeing clinical trials as a way of using patients to achieve goals related to the functioning of pharmaceutical companies [11] is always justified, all the more that this criticism never refers to life-threatening diseases or irretrievable loss of health. It should be emphasized that clinical trials concern diseases located in the highest hierarchical structure, which results from their clear definition in relation to the biomedical model, whereas medicalization usually concerns less precise states, e.g. regarding mental health $[16,17]$. In the absence of effective methods of controlling certain diseases and treatment that would stop the progression of the disease, society grows impatient, questions the competence of research teams and criticizes the search for new effective therapies as being too long, often taking years, and not always successful. Therefore, lack of faith in the effectiveness of clinical trial results is reinforced by a general sense of deficiency and disappointment with modern medicine, related to the fact that it is impossible for medical professionals to implement the 'therapeutic scenario' construct, 


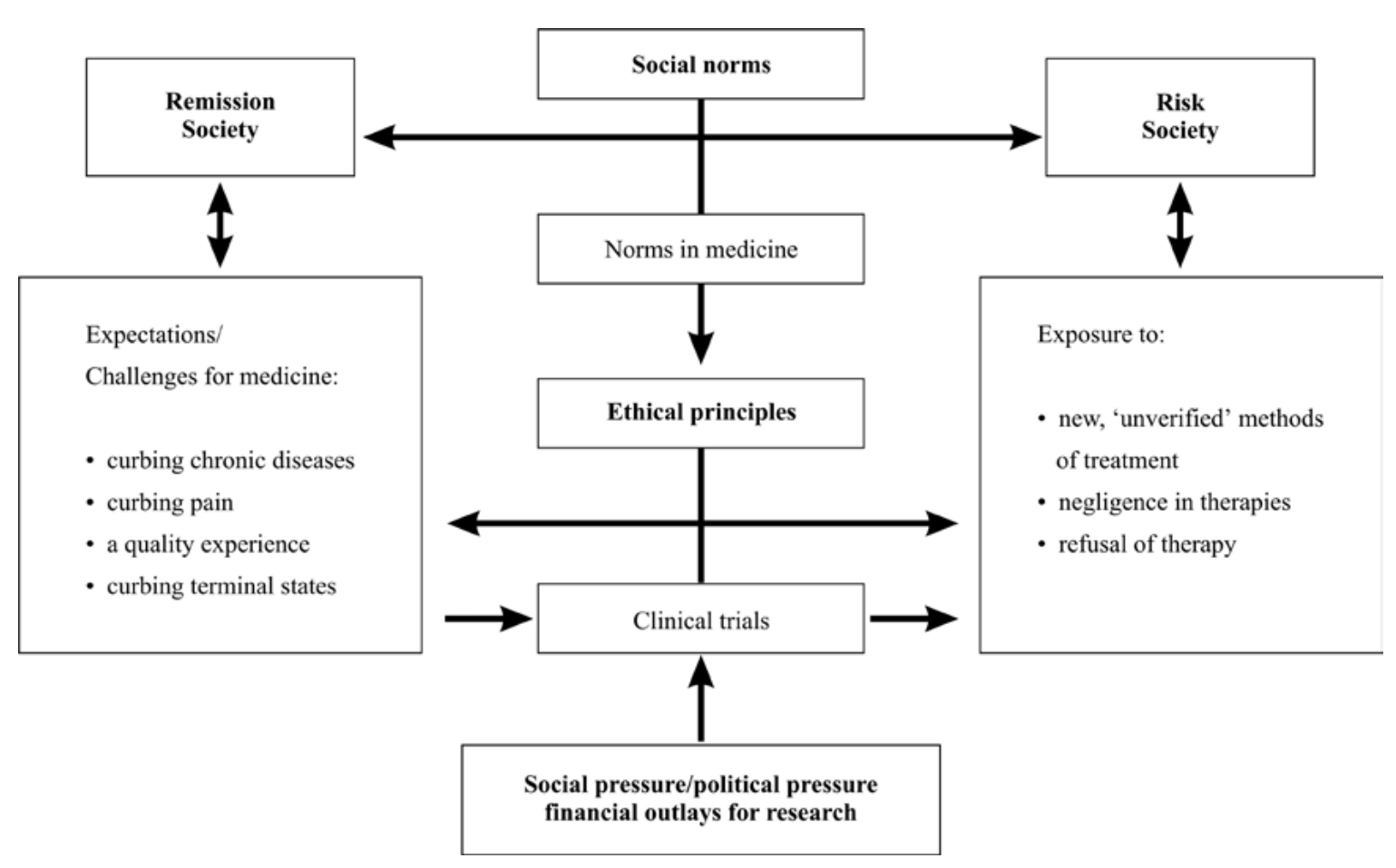

Figure 1. Multidimensional model showing the relation between remission society and risk society.

Source: Own study.

according to which all patients are effectively treated and morbidity and mortality rates are visible reduced.

\section{Poles' attitude towards clinical trials}

There have been very few studies on Poles' attitude towards clinical trials. The difficulty in assessing the value of these studies results from the different methodologies used and the different size of the groups in which the research was carried out. A small study conducted in a group of 100 people over 18 showed a negative attitude to clinical trials, also identifying the need to conduct such tests. For the majority of respondents, drug testing was associated with a threatened sense of security, and almost half of the respondents would not recommend a relative or a friend to participate in a program of testing new drugs [18].

A larger study, i.e. the PBS DGA Report conducted in 2010 involving a representative group of Poles, also yielded doubtful results, since it was a commissioned study, and so the results of the report should be treated with caution [19]. The results of the PBS DGA Report indicated a great interest of Poles in clinical trials: $2 / 3$ of those surveyed heard about clinical trials, i.e. drug testing, and the percentage of people responding positively to this question rose with increasing education: $52 \%$ of people with primary education heard about clinical trials, compared to $71 \%$ people with secondary education and nearly $89 \%$ people with higher education. The least willing to participate in clinical trials were elderly people (over 59 years of age) who - also less frequently than other participants of the study - heard of clinical trials.
To those who have heard about clinical trials, they were associated primarily with medical progress (35\%), with experiment $(30 \%)$, with the introduction of new drugs $(28 \%)$, and with a chance to improve patients' health (21\%). Other responses included the indication of risk, danger for patients $(12 \%)$, financial benefits for patients $(6 \%)$, unfair activity of pharmaceutical companies, aimed at increasing sales of a given drug (5\%), financial benefits for doctors $(4 \%)$, deterioration of patients' health $(3 \%)$. The options presented to the participants regarding the potential serious threat to their health (e.g. in the case of diabetes) and the choice between the standard treatment method and the possibility of participating in a clinical trial testing a new, more effective method, have shown that the decision to participate in such a clinical trial was taken by an average of $60 \%$ of respondents, while in the situation of the diagnosis of cancer, participation in the clinical trial was declared by $3 / 4$ respondents of those who heard of clinical trials (39\% expressed a strong desire to participate in the experimental method, while $23 \%$ would not take such a step) [19].

Commenting on the results of the PBS DGA Report, Prof. Z. Szawarski said: "Poles are eager to participate in research, because they are primarily driven by their own interest", excluding participation in research due to other motives, such as "strictly moral reasons: altruism, solidarity, moral duty, religious considerations" [19].

Clinical trials have given rise to many fallacies and negative emotions, mainly concerning the rules of participation in them, such as the way of recruiting people who are ill or healthy, determining the social position of beneficiaries of clinical trials (individuals, groups of pa- 
tients of a certain age, education, health status, chances of full recovery), social messages accompanying clinical trials, and social and economic costs incurred due to these studies. Of particular importance are social costs resulting from mistakes committed when introducing drugs before they have been fully tested or promoting such drugs, illustrated by the example of Thalidomide - the infamous drug advertised as an effective means of preventing adverse symptoms accompanying pregnancy, which should be a warning to all actors involved in clinical trials; as a result of using this preparation, about 10,000 children were born with hypoplasia of upper and lower limbs.

Taking into account the years of discussion and serious consideration of the role of medicalization and pharmaceuticalization of social life, of negative consequences of these processes and taking action towards demedicalization of social life [2] - even the negative consequences of unjustified, or even unauthorized medicalization - the fact that the fight against modern diseases is not possible without clinical trials cannot be obscured.

Poland belongs to countries with one of the lowest rates of clinical trials (currently below 400), as well as the lowest number of patients included in these studies [19]. Accordingly, do these indicators (contrary to the respondents' declarations from the study cited) point to negative social attitudes towards clinical trials, or do they result from low public awareness, lack of reliable knowledge about clinical trials, underestimation of their role in modern medicine, especially in relation to the situation of people who are currently suffering from an illness, particularly those suffering from diseases that cause loss not only of health but also life, or are an expression of wider social attitudes, which include loss of trust in doctors, medical institutions, pharmaceutical companies, or the motive for which research is carried out being assessed as low, or undermining the reliability of results, and finally the 'suspicious' role of sponsors in obtaining results?

Taking into account the variety of conditions determining social attitudes towards clinical trials, it is difficult to give an unequivocal answer - most probably the increase in public awareness of new medical technologies is a desirable factor, just like the expectation of ensuring safe use of drugs or therapies, and finally - expectations related to personalized medicine $[20,21]$.

The diverse emotions accompanying clinical trials are not only connected with the clinical aspect of these studies, but are primarily focused on social aspects related to social trust as defined by P. Sztompka, who points to the significant role of trust in relations with medical institutions. According to P. Sztompka, "trust becomes the basic strategy of dealing with uncertainty and inability to control the future (...) trust has a specific addressee and its foundation are the expected reactions of others to the trust we place in them". Expressing consent to participate in a clinical trial is an act of confidence - "entrusting oneself, the most precious values of one's health or life" [22]. Signing consent to participate in a clinical trial, submitting oneself to new, often experimental therapy, also means "renouncing a part of control over one's own destiny and the decision to become partially vulnerable and incapacitated" [22].

Regarding participation in a clinical trial, social expectations also concern the extent to which its organizers meet their obligations towards the participant confiding in them to confirm the reliability of research and results, demonstrating that the clinical trial is controlled in order to monitor its possible negative consequences, and in the event of their occurrence, to interrupt testing, ensuring the participants' safety and eliminating any side effects. The fact that a participant places their trust in a medical institution or a team of researchers carrying out the clinical trial, should oblige them even more to comply with all the ethical principles currently required.

The decision related to participating in a clinical trial is not immune from risk resulting from the possibility of unforeseen adverse effects or lack of expected results (health improvement), as well as the failure to fulfil the hope associated with the study. The consent to undergo therapy involving new drugs or other forms of experimental therapy is always associated with a health risk, or possible side effects. These risks may cause the participants to decide to withdraw from the study, or the research team to decide to discontinue the clinical trial after analyzing the benefits and losses (costs) associated with it.

The institutionalized risk in the case of clinical trials undertaken by medical institutions is closely related to the principles of the functioning of these institutions. Public trust in medical institutions conducting clinical trials, as well as pharmaceutical concerns, usually appearing as sponsors of clinical trials, is the result of collective or individual experiences [23].

Gałuszka [24], in turn, draws attention to the pharmaceutical risks associated with the production and distribution of medicines and the organization of medical services as well as risks resulting from medical errors. Referring to contemporary bioethics, Gałuszka [24] points to four main principles: the principle of autonomy, doing good, avoiding evil and of justice.

\section{The role of patients in clinical trials}

The messages addressed to the public not only indicate that there would be no new therapies without research, but also strongly emphasize the importance of the participation of volunteers or patients since clinical trials simply cannot be conducted without their participation. Patients taking part in clinical trials validates them, at the same time giving the participants the moral right to decide in which clinical trials they want to be included (patients' decision), the more so because patient provides information about how to assess their quality of life during and after the tests; this knowledge enriches the knowledge of researchers with valuable data.

Patients' organizations emphasize the role of patients in clinical trials, often pointing to altruism as the reason to participate. Showing the significance of the role they play - by appreciating the opinion and views of patients, and the increasing knowledge about their task - is aimed 
also at convincing other people to take part in research. The importance of involving patients in research development (according to the European Patients' Academy) is highlighted.

The group whose participation in clinical trials is chiefly discussed are elderly people. On the one hand, there is a small number of elderly people taking part in clinical trials, which means that they are more likely to take medicines that have not been tested for their age group or are refused treatment because of the lack of data on the effectiveness of certain drugs in the older age group [25]. K. Szczerbińska cites the results of a review of clinical trials on the most characteristic diseases affecting the elderly (e.g. heart failure, hypertension, Alzheimer's disease, depression, Parkinson's disease, cancer), which clearly prove scarce participation of the elderly in these studies. On the other hand, though, research shows that medical workers seldom recruit older people for clinical trials, especially when this participation does not have a clear benefit for the elderly patient. In addition, older patients are perceived as reluctant to undergo changes in their current treatment, expressing fear of experiments, or being an object of experience, and refusing to participate in these studies [25]. Research aimed at establishing the attitudes of medical workers towards including the elderly in clinical trials has shown that more than half of Polish medical employees agree with the statement that older age should not be an obstacle to inclusion in clinical trials, especially so because about $88 \%$ of respondents confirm that older people are not sufficiently represented in clinical trials. Objective obstacles related to the participation of the elderly in clinical trials are associated with the frequent occurrence of many concomitant diseases in the elderly, taking too many medicines, cognitive impairments, more frequent adverse events, disability, difficulties in recruiting older people for research, and a higher probability of refusing to participate in the study, lack of interest of older people in clinical trials and a greater probability of the elderly not complying with the requirements [26].

Due to communication barriers in reaching the institution offering participation of elderly people in research while guaranteeing their rights and respect for health, the Charter of the Rights of the Elderly has aided the efforts to increase older people participation in clinical trials. It defines the conditions for obtaining informed consent for participation in clinical trials, information about the purpose of the experiment, the expected benefits and possible risks, and discomfort that can be experienced by the person taking part in the study. The consent to participate in the study must be confirmed in writing or with the presence of witnesses [27].

Slogans, such as "women in clinical trials - make changes for the better - ask your doctor if clinical trials are right for you", promoted by the FDA Office of Women's Health raise the question whether the incentive to participate in clinical trials is an expression of another (unnecessary) interference of medicine in women's health? Do promotional materials containing "facts that you should know before you become a participant in a clinical trial" serve to manipulate women's decisions by pointing to participation in clinical trials as an independent decision? [28].

In summary, information addressed to potential participants in clinical trials should indicate the quality of clinical trials, their transparency, type of study and its subject, the number of patients, research goals, and sources of financing. Participants should receive information during clinical trials on the doses of medication received, be asked about or report positive and negative effects (side effects). Also, the final results of clinical trials (data) and the interpretation of the research process should be presented to study participants primarily from the perspective of their safety.

\section{Communicating test results}

The development of new drugs is a long-lasting process, and so informing on the complexity of the drug development process, the legal and ethical regulations in place used to monitor the process and ensure the safety of medicines, can enhance confidence in such undertakings $[29,30]$.

Messages addressed to the public concerning clinical trials, recipients of this information and especially their results, depend on the health literacy [24], which constitutes a significant obstacle in understanding the purpose of clinical trials and in relations based on partnership and mutual communication between the participant of clinical trials and the research team [31].

The results of clinical trials are not always published; in such cases, the lack of publication of certain results requires clarification. The public expects researchers to provide reliable information on the results of clinical trials [32]. The results of clinical trials published in scientific journals do not usually reach the wider public, and are rarely advertised in the press available to laymen.

The public wants to have access to the results of clinical trials: patients wish to know their results to make decisions about continuing treatment, interpreting emerging side effects or deciding about seeking alternative treatment. The language of information adapted to the knowledge of lay people consists in verbal and symbolic messages: what to say and how, to whom and in what form, so as not to induce negative emotions and bad reactions. The information provided to the public should discuss positive and negative results, prevent selective publication of results, especially taking into account the consequences that publishing these results would have for the people actively using the results of these studies (i.e. patients).

\section{The role of the medlia in providing information on clinical trials}

The interest of the media and decision-makers associated with treatment policy should play an important role in disseminating research results through modern information channels. Their popularization should take place via the Internet, social media: e-mails, blogs, Twitter, social networks, including patient organizations. 


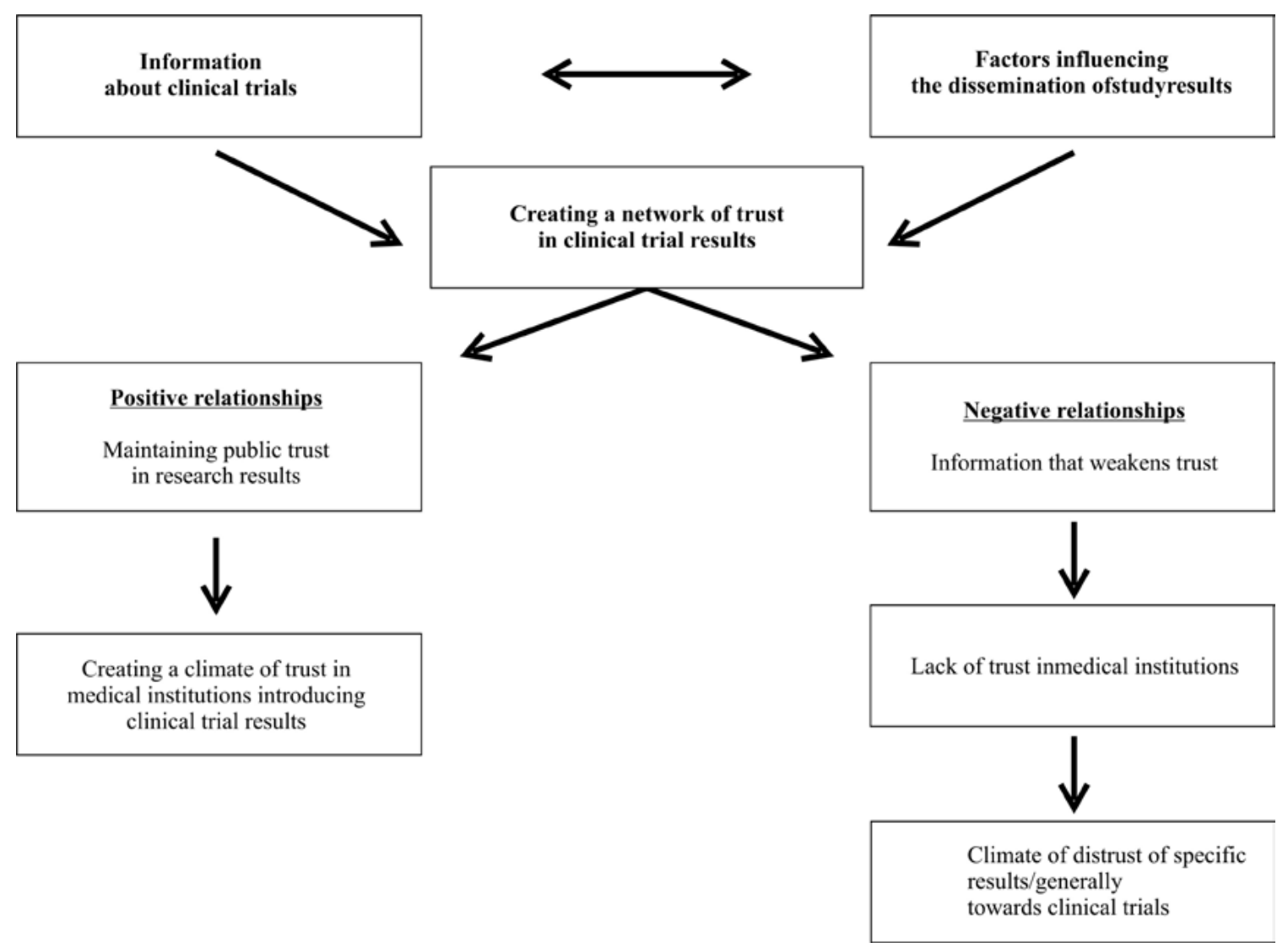

Figure 2. Factors creating a network of trust in clinical trial results.

Source: Own study.

\begin{tabular}{|c|c|}
\hline 1. Clinical trials are dangerous. & $\begin{array}{l}\text { Ill people receive a medicine that has been previously tested - while the new } \\
\text { drug is researched, they are under medical supervision. }\end{array}$ \\
\hline $\begin{array}{l}\text { 2. Pharmaceutical companies do what they like, no one } \\
\text { controls them. }\end{array}$ & $\begin{array}{l}\text { Nonsense - the need to fulfil formalities - obtaining the consent of the } \\
\text { bioethical commission. }\end{array}$ \\
\hline 3. Doctors use patients and put their health at risk. & $\begin{array}{l}\text { Incorrect - the patient may start clinical trials only after giving written con- } \\
\text { sent, and after receiving information about all adverse reactions connected } \\
\text { with the study. They can withdraw from the study at any time. }\end{array}$ \\
\hline 4. Patients earn money on clinical trials. & - Healthy volunteers YES; patients receive medical care and free medicines. \\
\hline
\end{tabular}

Table I. An example of a media message by "Super Express".

Source: http://www.se.pl/wiadomosci/polska/obalamy-mity-o-badaniach-klinicznych_426085.html (accessed: 20.11.2018) [33].

An example of a media message about clinical trials is that prepared by "Super Express". However, it should be emphasized that this message does not remove all doubts (Table I).

\section{Summary}

The rules regulating the inclusion of various groups of patients or healthy people in clinical trials depend on social attitudes towards research in medicine, but also on the attitudes of the social environment (network of social relations) assessing the way of recruiting for research or participation in research from the perspective of groups represented in studies and social groups not participating in them.

Social attitudes are based on evaluating the objective benefits of participating in research, but the subjective norms and attitudes of family and friends towards clinical trials also play an important role. The significance attributed to medical research has an important impact on the participation of healthy volunteers in such studies, and is associated with many ethical questions.

Inequalities in approaching different groups of patients include considering the question whether it is worth carrying out research in a small number of patients suffering from a disease that is to be the subject of clinical 
trials, especially if this group of patients requires costly therapies, or the opposite situation - too many patients included in the clinical trial.

Debating clinical trials with the public should be treated as part of the clinical trial project, on an equal footing as legislative activities and the registration of clinical trial results. References to such authorities as the Cochrane Collaboration Group or medical professionals, can be reinforced by providing medical information not only in medical journals, but also through social networks, and the promotion of clinical trials on the Internet. Changes in social attitudes may be expected to occur through the dissemination of knowledge about the real role of clinical trials in the modern world, counteracting the "culture of distrust' towards clinical trials, gradual building of social trust in clinical trials, 'attracting' patients to research rather than 'pushing them away', increasing the capacity to understand messages about various aspects of clinical trials, appreciating the role of patients as co-authors of clinical trial results, and the role of mass media in the objective dissemination of clinical trial results.

\section{References}

1. Ostrowska A., Medykalizacja - perspektywa uzurpatora, in: Nowakowski M., Piątkowski W. (eds.), Procesy medykalizacji we wspótczesnym spoleczeństwie, Wydawnictwo Uniwersytetu Marii Curie-Skłodowskiej, Lublin 2017: 42-50.

2. Słońska Z., Medykalizacja a spoteczeństwo: obszary i kierunki wzajemnego oddziatywania, in: Nowakowski M., Piątkowski W. (eds.), Procesy medykalizacji we wspótczesnym spoleczeństwie, Wydawnictwo Uniwersytetu Marii Curie-Skłodowskiej, Lublin 2017: 51-62.

3. Nowakowski M., Medykalizacja i demedykalizacja: zdrowie i choroba $w$ czasach kapitalizmu zdezorganizowanego, Wydawnictwo Uniwersytetu Marii Curie-Skłodowskiej, Lublin 2015.

4. Nowakowski M., Piątkowski W., Procesy medykalizacji we wspótczesnym społeczeństwie, Wydawnictwo Marii Curie-Skłodowskiej, Lublin 2017.

5. Tobiasz-Adamczyk B., Proces medykalizacji a zmiany we wzorach odzywiania, in: Tobiasz-Adamczyk B. (ed.), Od socjologii medycyny do socjologii żywienia, Wydawnictwo Uniwersytetu Jagiellońskiego, Kraków 2013: 21-25.

6. Pescosolido B.A., Taking “The Promise” Seriously: Medical Sociology's Role in Health, Illness, and Healing in a Time of Social Change, w: Pescosolido B.A., Martin J.K., McLeod J.D., Rogers A. (eds.), Handbook of the Sociology of Health, Illness, and Healing. A Blueprint for the $21^{\text {st }}$ Century, Springer, New York-Dordrecht-Heidelberg-London 2011: 3-20.

7. Pescosolido B.A., Organizing the Sociological Landscape for the Next Decades of Health and Health Care Research: The Network Episode Model III-R as Cartographic Subfield Guide, in: Pescosolido B.A., Martin J.K., McLeod J.D., Rogers A. (eds.), Handbook of the Sociology of Health, Illness, and Healing. A Blueprint for the $21^{\text {st }}$ Century, Springer, New York-Dordrecht-Heidelberg-London 2011: 39-66.

8. Giddens A., Zdrowie, choroba i niepetnosprawność in: Socjologia. Rozdział 10. Wydanie nowe, tłum. Olga Siara,
Alina Szulżycka, Paweł Tomanek, Wydawnictwo Naukowe PWN, Warszawa 2012.

9. Charmaz K., Loss of self: A fundamental from of suffering in the chronically ill, in: Scambler G. (ed.), Medical Sociology. Major Themes in Health and Social Welfare, Routledge, London-New York 2005: 161-185.

10. Moynihan R., Cassels A., Selling Sickness: How the World's Biggest Pharmaceutical Companies are Turning Us All Into Patients, Nation Books, New York 2005.

11. Niebrój L.T., Sprzedawcy chorób: etyczne granice stosowania normatywistycznych definicji zdrowia/choroby, in: Nowakowski M., Piątkowski W. (eds.), Procesy medykalizacji we współczesnym społeczeństwie, Wydawnictwo Marii Curie-Skłodowskiej, Lublin 2017: 65-77.

12. Kaufman D., Murphy J., Scott J., Hudson K., Subjects matter: A survey of public opinions about a large genetic cohort study, "Genetics in Medicine" 2008; 10 (11): 831-839.

13. Tobiasz-Adamczyk B., "Życie w ramach” wyznaczonych choroba nowotworowa - rola socjologii medycyny, "Przegląd Socjologiczny" 2012; LXI (2): 81-118.

14. Frank A.W., The Wounded Storyteller: Body, Illness, and Ethics. IL University of Chicago Press, Chicago 1995.

15. Beck U., Społeczeństwo ryzyka. $W$ drodze do innej nowoczesności, Wydawnictwo Naukowe Scholar, Warszawa 2002.

16. Grue J., Johannessen L.E.F., Rasmussen E.F., Prestige rankings of chronic diseases and disabilities. A survey among professionals in the disability field, "Social Science and Medicine" 2015; 124: 180-186.

17. Antman E., Bassand J.P., Klein W., Ohman M., Lopez Sendon J.L., Rydén L. et al., Myocardial infarction redefined - A consensus document of The Joint European Society of Cardiology/American College of Cardiology Committee for the redefinition of myocardial infarction, "Journal of the American College of Cardiology" 2000; 36 (3): 959-969.

18. Graboń A., Olejniczak D., Religioni U., Postawy Polaków wobec badań klinicznych II i III fazy, "Farmacja Polska" 2013; 69 (1): 19-25.

19. Badania kliniczne w Polsce - "eksperyment" na ludziach czy dla ludzi?, On board Public Relations ECCO Network, Warszawa 2010.

20. Caron-Flinterman J.F., Broerse J.E.W., Bunders J.F.G., The experiential knowledge of patients: A new resource for biomedical research? "Social Science and Medicine" 2005; 60 (11): 2575-2584.

21. Abramowicz B., Ryzyko jako kategoria analityczna w naukach społecznych - kontekst polityczny i społeczny, in: Gałuszka M., Wieczorkowska M. (red.), Społeczne, kulturowe i polityczne uwarunkowania ryzyka zdrowotnego, Uniwersytet Medyczny w Łodzi, Łódź 2000: 67-84.

22. Sztompka P., Zaufanie. Fundament Spoleczeństwa, Znak, Kraków 2007.

23. Gałuszka M., Medycyna i zdrowie w społeczeństwie ryzyka, in: Gałuszka M. (ed.), Zdrowie i choroba w spoleczeństwie ryzyka biomedycznego, Wydawnictwo Uniwersytetu Medycznego, Łódź 2008: 54-106.

24. Gałuszka M., Kompetencja zdrowotna w społeczeństwie ryzyka biomedycznego, in: Gałuszka M., Wieczorkowska M. (eds.), Społeczne, kulturowe i polityczne uwarunkowania ryzyka zdrowotnego, Uniwersytet Medyczny w Łodzi, Łódź 2012: 85-104. 
25. Szczerbińska K., Zalewski Z., Gąsowski J., Hartman J., Cwynar M. et al., Udziat osób starszych w badaniach klinicznych - prezentacja założen projektu PREDICT, “Gerontologia Polska" 2010; 18 (4): 176-182.

26. Szczerbińska K., Cwynar M., Zalewski Z., PREDICT i grupa projektu, Jak zwiększyć udziat osób starszych w badaniach klinicznych wedtug opinii polskich uczestników projektu PREDICT, "Gerontologia Polska" 2012; 20 (2): $45-52$.

27. Szczerbińska K., Zalewski Z., Salvà J.O., Karta praw osób starszych dotyczaca ich udzialu w badaniach klinicznych, "Zdrowie Publiczne i Zarządzanie" 2011; 1 (9): 119-127.

28. Kobiety $w$ badaniach klinicznych; https://www.fda.gov/ downloads/ForConsumers/ByAudience/ForWomen/Free Publications/UCM555505.pdf (accessed: 25.11.2017).
29. Ghersi D., Clarke M., Berlin J., Gülmezoglu A., Kush R., Lumbiganon P. et al., Reporting the findings of clinical trials: a discussion paper, "Bulletin of the World Health Organization" 2008; 86 (6): 492-493.

30. Godlew B.J., Furlong P., Transparency as a means to increase clinical trial enrollment, "Drug Information Journal" 2010; 44 (3): 265-270.

31. Laine C., Horton R., DeAngelis C.D., Drazen J.M., Frizelle F.A., Godlee F. et al., Clinical Trial Registration - Looking Back and Moving Ahead. "New England Journal of Medicine" 2007; 356 (26): 2734-2736.

32. Nassi-cal L., Unpublished results from clinical trials distort medical research, 2017.

33. http://www.se.pl/wiadomosci/polska/obalamy-mity-o-badaniach-klinicznych_426085.html (accessed: 20.11.2018). 